九州大学学術情報リポジトリ

Kyushu University Institutional Repository

BEES OF THE GENUS PALAEORHIZA PERKINS (HYMENOPTERA, COLLETIDAE) IN THE NATIONAL FOREST INSECT COLLECTION OF THE FOREST RESEARCH STATION, BULOLO, PAPUA NEW GUINEA ( I )

Hirashima, Yoshihiro

Roberts, Hywel

https://doi.org/10.5109/2458

出版情報: ESAKIA. 22, pp.115-128，1984-11-20. Entomological Laboratory，Faculty of Agriculture, Kyushu University

バージョン：

権利関係 : 


\title{
BEES OF THE GENUS PALAEORHIZA PERKINS (HYMENOPTERA, COLLETIDAE) IN THE NATIONAL FOREST INSECT COLLECTION \\ OF THE FOREST RESEARCH STATION, BULOLO, PAPUA NEW GUINEA ( I )*
}

\author{
Yoshiniro Hirashima \\ Entomological Laboratory, Faculty of Agriculture, \\ Kyushu University, Fukuoka 812, Japan \\ and \\ HYWEL ROBERTS \\ Forest Research Station, Department of Primary \\ Industry, Bulolo, Papua New Guinea
}

\begin{abstract}
Palaeorhiza in the National Forest Insect Collection of the Forest Research Station, Bulolo, Papua New Guinea is examined and 11 species are recorded in this paper. Four new species, P. (Heterorhiza) paris, P. (Palaeorhiza) priamus, P. (Cnemidorhiza) helena and P. spectabilis, are described from Papua New Guinea.
\end{abstract}

The material on which the present paper is based is collected by one of us, H. Roberts, in Papua New Guinea for the last few years and is preserved in the National Forest Insect Collection, the Forest Research Station, Department of Primary Industry, Bulolo, Papua New Guinea. It includes many interesting species, some of which are described as new in this paper.

The holotypes of the new species will be deposited in the collection of the British Museum (Natural History), London.

\section{(1) Palaeorhiza (Hadrorhiza) imperialis (Smith)}

Specimens examined : 2 females and 2 males, Divide L. A., Bulolo Valley, on Harpullia flowers, 7. ix. 1982 (H. Roberts).

* Contribution from the Entomological Laboratory, Faculty of Agriculture, Kyushu University, Fukuoka (Ser. 3, No. 161). 


\section{(2) Palaeorhiza (H adrorhiza) stellaris Hirashima}

This was originally described as a subspecies of Palaeorhiza Zieftincki Hirashima, but is treated here as a good species. It differs from Zieftincki primarily by darker (fuscus) hairs on the head and thorax, weaker and sparser punctures on the mesoscutum and different coloration of the body.

Specimens examined: 1 female and 3 males, Manki L. A., Bulolo Valley, on Rubus flowers, 2. viii. 1981 (H. Roberts).

Color variation: The present material differs from the holotype of stellaris as follows :

Legs purple (blue-green with purple tint in the type) ; head and thorax darker, dark blue-green with purple reflection ; and metasoma very shining, red-purple with brassy reflection (dark blue-green in the type).

It seems very probable that the metallic coloration is variable in the species-group of Zieftincki (cf. Hirashima and Lieftinck, 1982).

\section{(3) Palaeorhiza (Cheesmania) amabilis Hirashima}

This is a brilliantly metallic species. The male is similar to the female and also lacks yellow marking on the body. The male of Cheesmania which was recorded by Hirashima (1981) is probably the male of amabilis.

The present material (4 females and 3 males) shows color variation in both sexes. In one female and one male, the head and thorax are almost entirely violet or beautiful reddish purple, as in the metasoma. This feature is similar to the type series (holotype and 1 paratype) of amabilis, but the propodeum is blue-green in the type series and blue or blue-violet in the present material. On the other hand, in one female and one male, the thorax is nearly entirely blue-green except the sides of the thorax which are purple, and in one male the head and thorax are variegated with brassy, purple and blue-green. Thus Palaeorhiza amabilis is polymorphic as far as the color is concerned.

Specimens examined : 2 females and 1 male, Manki L. A., Bulolo Valley, on Asystasia flowers, 31. viii. 1982 (H. Roberts) ; 2 females and 2 males, the same locality, on Rubus flowers, 10. ix. 1982 (H. Roberts).

\section{(4) Palaeorhiza (Sphecogaster) paradisea Hirashima}

Specimens examined : 4 females, Mt. Kaindi summit, Morobe District, Papua New Guinea, on Uncaria flowers, 10. ix. 1982 (H. Roberts).

\section{(5) Palaeorhiza (Zarhiopalea) variegata Hirashima}

Specimens examined : 3 males, Gumi L. A., Bulolo Valley, Morobe Province, on Rubus flowers, 18. vi. 1981 (H. Roberts). 
The female of this species is still unknown.

(6) Palaeorhiza (Heterorhiza) cockerelli Hirashima and Lieftinck

Specimens examined : 4 females, Patep River, Morobe Province, on M imosa flowers, 25. viii. 1982 (H. Roberts).

\section{(7) Palaeorhiza (Heterorhiza) paris, new species}

This is unusual for the subgenus Heterorhiza in having the propodeal enclosure fluted on the basal half only, the posterior face of propodeum keeled on lateral margins, and the male hind femora considerably modified as described below. It seems very probable that this new species may represent a separate subgenus.

Female : Length slightly less than $8 \mathrm{~mm}$.

Relative head measurements ; width, 34.0 ; length, 36.8 ; upper interocular distance, 19.0 ; width of face, 22.5 ; lower interocular distance, 15.0 ; eye length, 28.0 ; length of clypeus, 17.0 ; length of malar space, 4.0 in the middle.

Head long ; inner margins of eyes distinctly converging below ; mandible nearly simple at apex ; malar space long, slightly shorter than basal width of mandible in the middle ; median portion of face well convex when the head is seen from side ; supraclypeal area rather low ; vertex very convex, posterior portion of vertex strongly slanting posteriorly ; ocelli rather small ; ocellocular distance about equal to ocelloccipital distance, slightly longer than interocellar distance which is twice as long as diameter of lateral ocellus. Clypeus, supraclypeal area and paraocular areas nearly impunctate, longitudinally lineolate, shining; vertex well punctate.
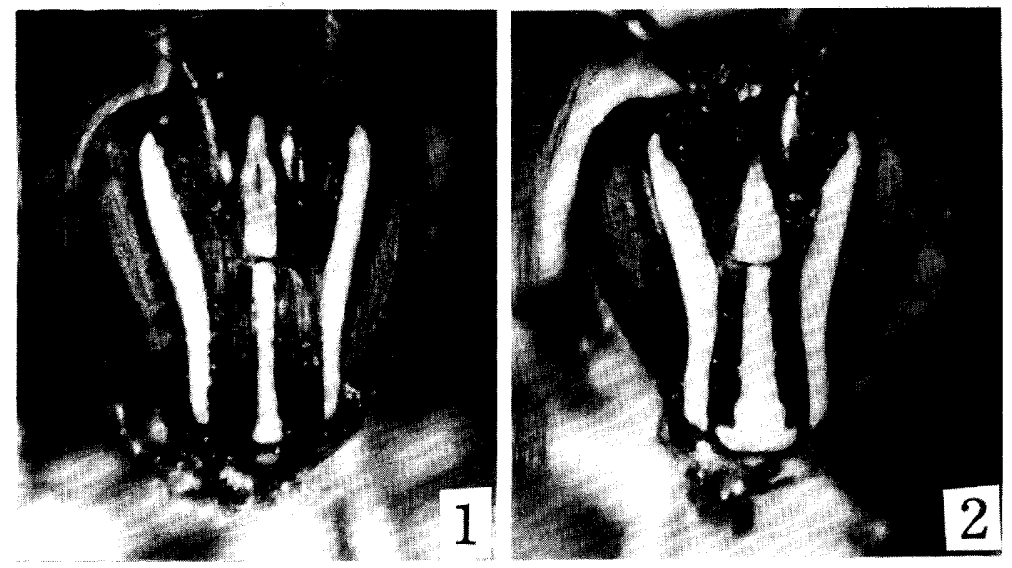

Figs. 1 and 2 Palaeorhiza (Heterorhiza) paris, new species. 1 : Frontal view of the head of female. 2 : Ditto, male. 
Collar of pronotum well developed on lateral portions ; mesoscutum nearly smooth, shining, strongly punctate, but punctures more or less sparse, irregular in distribution ; scutellum rather flat, smooth, shining, with rather sparse punctures which are irregular in size and distribution; metanotum smooth, shining, with sparse and weak punctures ; propodeum coarsely sculptured with strong, dense punctures ; propodeal enclosure fluted-punctate or coarsely wrinkled on basal half or so ; posterior face of propodeum strongly keeled on lateral margins ; pre- and meso-episternum nearly smooth, shining, strongly, rather densely punctate ; punctures on uppper portion of mesepisternum weak ; lateral face of propodeum finely sculptured.

Fore tarsi rather slender with well developed polliniferous hairs as usual for the subgenus ; 2nd segment of fore tarsi small, a little longer than broad, slightly larger than next segment ; inner spur of hind tibia strongly pectinate ; base of hind tibia with a small, elongate, slightly elevated, smooth area dorsally; hind femur longitudinally ridged ventrally (usually rounded in Palaeorhiza).

Metasoma with 1 st tergum large, well convex on laterobasal portions; three basal terga largely exposed and three apical terga retractile. First tergum shining, with rather distinct punctures, apical margin broadly impunctate on median portion ; 2nd tergum with more distinct punctures, which are more or less weak and sparse medially and dense and strong laterally; apical impunctate margin of 2nd tergum broad, well indicated ; 3rd tergum with punctures coarser than those on 2nd.

Color : Black. Head and thorax with following markings or portions yellow : three stripes on face, round spot on labrum, basal spot on mandible, complete band on pronotum, four longitudinal lines on mesoscutum (lateral ones shorter), axilla, a pair of broad longitudinal marks on lateral portion of scutellum, band on metanotum (notched in the middle anteriorly), triangular mark on propodeal enclosure, mark on tubercle and transverse band (interrupted) on sides of thorax just below wing bases ; line on genal area along eye margin piceous. Wings strongly brownish nearly all over ; veins and stigma fuscous; tegulae brown, subtranslucent, with a small yellow spot. Legs piceous; basal half of fore tibia yellowish anteriorly. Metasoma shining black ; about apical half of 1 st tergum piceous or more reddened ; median portion of 2 nd tergum transversely reddened in the middle.

Pubescence : Not conspicuous, sparse and whitish on head and thorax ; metasomal terga without hair fringe ; hairs on apical segments of metasoma nearly black.

Male : About as large as female.

Relative head measurements ; width, 33.5 ; length, 36.7 ; upper interocular distance, 17.0 ; width of face, 20.7 ; lower interocular distance, 13.0 ; eye length, 27.5 ; clypeal length,, 17.7 ; length of malar space, about 4.8.

Agrees with the description of female except as follows : Malar space about as long as basal width of mandible ; median yellow stripe of face broadened laterally on apical portion of clypeus ; labrum and mandible nearly all yellow ; mesepisternum with longitudinal yellow stripe anteriorly ; side of propodeum with transverse, short, yellow line ; 1st metasomal tergum with or without a pair of yellow short bands medially ; anterior faces of femora and tibiae of fore and mid legs yellow. Scape rather short 


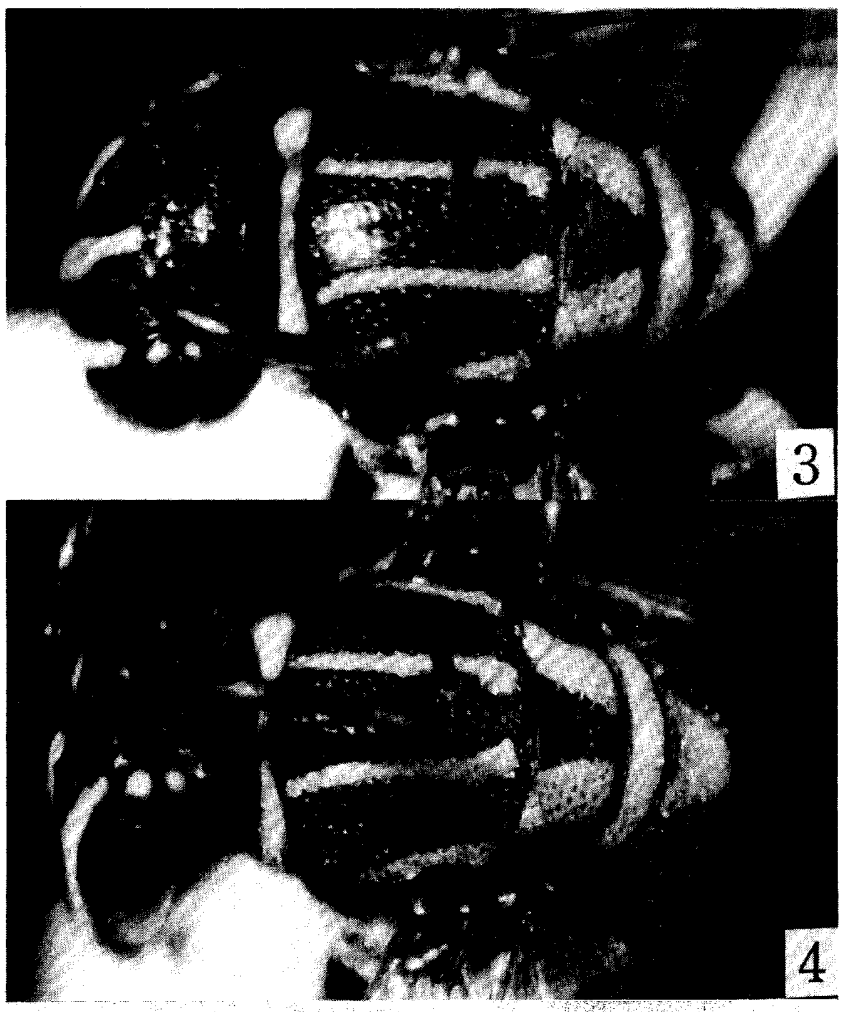

Figs. 3 and 4 Palaeorhiza (Heterorhiza) paris, new species. 3: Dorsal view of the head and thorax of female. 4 : Ditto, male.

for the size of head; flagellum rather long, with 1st segment small, about as long as broad, 2nd broader than long, 3rd longer than broad and about equal to 1st and 2nd combined. Hind femur strongly swollen, sublamellate posteriorly : underside of hind femur excavated, densely covered with decumbent white hairs. Metasoma long ; 1st metasomal tergum large, well convex and rounded ; 7th tergum with three long projections apically; the median projection subtriangular, the lateral ones more or less broad, not nail-like (nail-like in most species of Heterorhiza).

TYPE MATERIAL: Holotype female, 1 paratype female and 2 paratype males, Divide L. A., Bulolo Valley, Morobe Province, on Harpullia flowers, 6. ix. 1982 (H. Roberts).

Distribution: Papua New Guinea.

The specific name is derived from the Greek mythological name Paris.

(8) Palaeorhiza (Palaeorhiza) priamus, new species

Hirashima (1978) reported a banded-species (unnamed) of the subgenus Palaeorhiza from New Guinea, which is very close to the present new species. The new species, priamus, is distinctive in having white hair bands on the three basal metasomal terga 
and is easily separable from other members of the subgenus on this character. This is also very conspicuous in having a rich decoration of whitish marks on the head, thorax and legs, as described below.

Female : Length about $9 \mathrm{~mm}$, fore wing about $7 \mathrm{~mm}$.

Relative head measurements : width, 39.0 ; length, 34.5 ; upper interocular distance, 18.5 ; eye length, 29.1 ; length of clypeus, 14.0.

Inner eye margins distinctly converging below ; vertex, as seen in front, not specially convex ; malar space very narrow anteriorly', broadened posteriorly ; clypeoocular distance rather narrow, but broader than anterior portion of malar space ; clypeus and supraclypeal area well convex when the head is seen from side ; supraclypeal area broad, flat, dilated laterally ; ocelli close together ; posterior ocelli rather large, on top of vertex ; vertex behind ocelli distinctly slanting posteriorly ; interocellar distance about two-thirds as long as ocellocullar distance, about 1.8 times as long as diameter of lateral ocellus ; ocelloccipital distance slightly shorter than ocellocular distance. Head weakly punctate; frons lateral to frontal line and spaces above

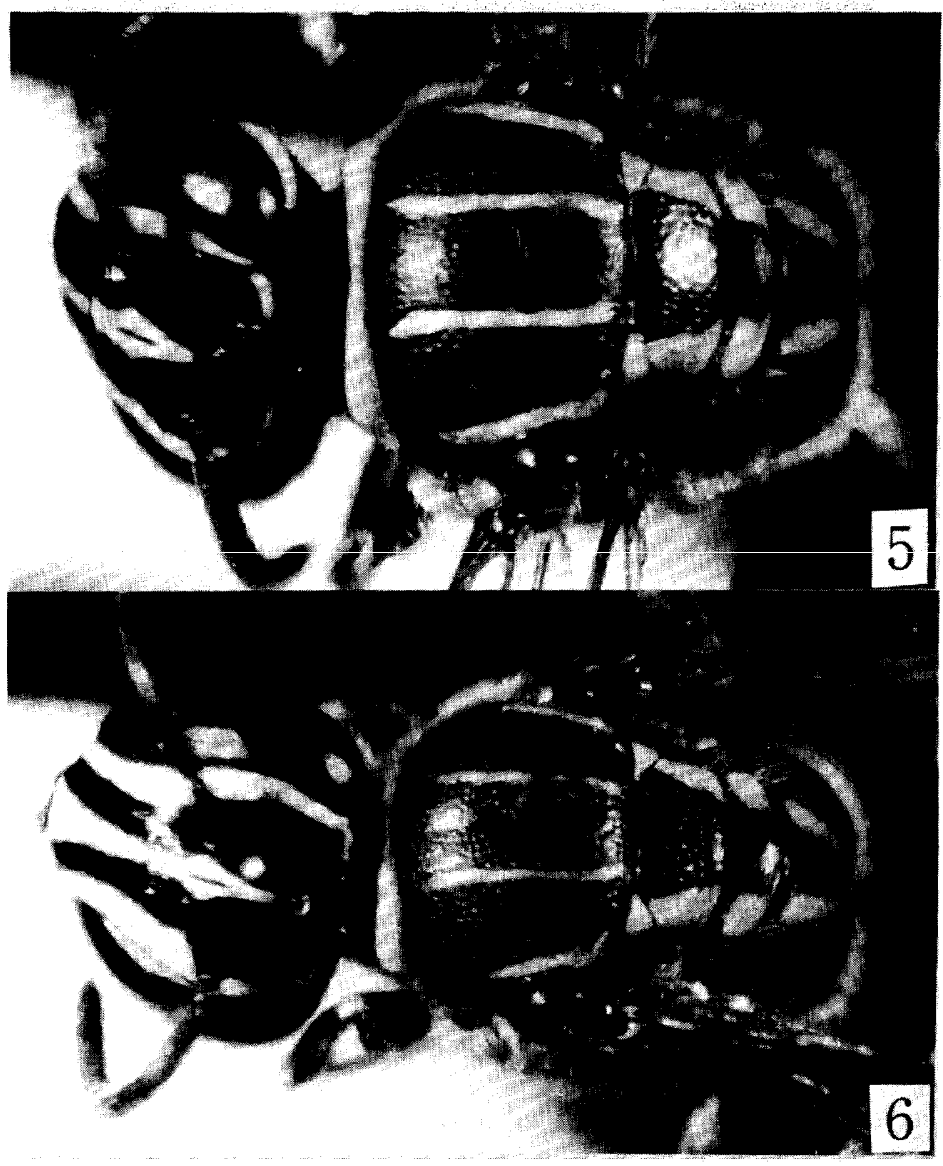

Figs. 5 and 6 Palaeorhiza (Palaeorhiza) priamus, new species. 5 : Dorsal view of the head and thorax of female. 6: Ditto, male. 
antenna1 sockets impunctate ; upper portion of frons and vertex well punctate.

Collar of pronotum more or less low, rather flat dorsally, distinctly narrowed in the middle ; mesoscutum rather strongly, more or less densely punctate on microscopically tessellate ground, rather shining; scutellum rather flat, well punctate like posterior portion of mesoscutum ; metanotum nearly smooth with very weak punctures ; propodeum as described for the subgenus (Hirashima, 1978) ; propodeal enclosure well indicated, impunctate, microscopically reticulate, nearly smooth, shining; pre- and meso-episternum nearly smooth but reticulate-punctate, punctures considerably weaker than those on mesoscutum.

Stigma of fore wing moderate in size ; 2nd submarginal cell large, slightly more than two-thirds as long as 1st along lower margin ; 1st abscissa of 2nd submarginal cell shorter than cubital vein, much longer than 3rd abscissa.

Legs rather slender, as usual for Palaeorhiza s. str.; inner spur of hind tibia distinctly pectinate ; a slender, elevated, smooth plate or area on base of hind tibia.

Metasoma with three basal terga broadly exposed and three apical terga retractile ; 2nd tergum distinctly constricted at base, well convex on median portion ; punctures on 1st tergum weak, those on 2nd stronger, those on 3rd stronger or larger than those on 2nd ; impunctate apical margin of 1 st tergum narrow, indicated on median portion only, that of 2 nd broad, well indicated, and that of 3rd broader than that of 2 nd.

Color : Dark metallic; head blackish with metallic blue tint, especially on frons and vertex ; thorax steel blue with very slight greenish tint ; head and thorax with following stripes or markings yellowish white with slight bluish tint : three longitudinal lines on face, transverse band on ocellocular space, long line on genal area along posterior margin of eye, antero-basal line on mandible, entire band on pronotum, four lines on mesoscutum (lateral one shorter), triangular mark on axilla, a pair of lateral longitudinal marks on scutellum, a pair of lateral transverse marks on metanotum, a pair of lateral longitudinal lines on propodeal enclosure, apical portion of tubercle, interrupted band on side of thorax below wing bases and longitudinal mark on mesepisternum along lower portion of pre-episternal groove ; legs piceous with slight blue and distinct purple tints ; with following markings or portions yellowish white ; basal half of anterior face of fore tibia, basal mark on mid tibia (not ring-like) and about basal one-third of hind tibia.

Pubescence : White on head and thorax, black on apical portion of metasoma ; hairs sparse on head ; posterior and lateral faces of propodeum with dense, dull gray hairs ; underside of thorax with dense, white hair patches mid-posteriorly ; three basal terga with interrupted bands of dense, white hairs.

Male : Slightly smaller than female.

Relative head measurements : width, 34.5 ; length, 32.0 ; upper interocular distance, 17.5 ; width of face, 22.0 ; lower interocular distance, 14.5 ; eye length, 26.8 ; length of clypeus, 14.5 .

Agrees with description of female except as follows: Head relatively longer than female ; lateral portion of clypeus longitudinally elevated ; malar space longer than in 
female, but less than half of basal width of mandible, still narrower than clypeo-ocular space; scape of antenna not specially long; flagellum with two basal segments broader than long, respectively, 2nd rather ring-like, 3rd slightly longer than broad and about as long as 1 st and 2nd combined ; mesepisternum with a slender transverse mark on medio-posterior portion which is contiguous or nearly so with anterior mark on mesepisternum ; fore legs with more whitish marks; hind coxae each with a slender, whitish mark ; apical margin of 4th sternum with a transverse fringe of short, subdecumbent, fuscous hairs.

TyPe Material : Holotype female, paratype male, Divide L. A., Bulolo Valley, Morobe District, on Harpullia flowers, 17. ix. 1982 (H. Roberts).

Distribution : Papua New Guinea.

The name of this new species is derived from the Greek mythological name Priamos.

\section{(9) Palaeorhiza (Cnemidorhiza) helena, new species}

This is a close relative of Palaeorhiza elegantissima (Dalla Torre), which was recorded from Misool by Hirashima and Lieftinck (1982), but is separable from it by the stronger punctures on the thorax and sparser punctures on the metasoma.

Female : Length about $8 \mathrm{~mm}$.

Relative head measurements : width, 35.8 ; length, 32.5 ; upper interocular distance, width of face, 23.0 ; lower interocular distance, 18.5 ; eye length, 26.0 ; clypeal length, 13.0.

Very close to elegantissima, but differs from it as follows : face relatively broader and shorter (relative head measurements of elegantissima from Misool : width, 37.5 ; length, 34.5 ; upper interocular distance 18.5 ; width of face, 23.0 ; lower interocular distance, 18.5 ; eye length, 28.0 ; clypeal length, 14.0 ); clypeus and lower portion of supraclypeal area slightly more convex; punctures on frons and vertex stronger ; mesoscutum and scutellum much more strongly punctate, punctures on mesoscutum about twice as large as those in elegantissima ; punctures on dorsal face of propodeum stronger and somewhat sparser; three basal terga more shining, with sparser punctures ; lateral yellow stripe on mesoscutum and transverse band on metanotum larger ; the median yellow stripe of face very close to mid ocellus (well separated from mid ocellus in elegantissima).

M ale : Slightly smaller than female.

Relative head measurements : width, 32.0 ; length, 31.0 ; upper interocular distance, 17.0 ; width of face, 19.5 ; lower interocular distance, 12.0 ; eye length, 25.5 ; length of clypeus, 13.0.

Eyes large ; inner eye margins distinctly converging below ; malar space not longer than in female, about half as long as basal width of mandible which is not broad ; clypeo-ocular distance slightly longer than malar space ; clypeus flat on upper portion ; upper portion of supraclypeal area narrow, highly elevated, abruptly lowered toward above ; ocelli rather small, well separated each other ; ocellocular distance 
about equal to interocellar distance, slightly shorter than ocelloccipital distance. Scape not long ; flagellum elongate ; 1st and 2nd segments broader than long respectively ; 3rd long, about equal to 1st and 2nd combined. Clypeus and paraocular area distinctly, sparsely punctate ; frons and vertex strongly, densely punctate ; small space just above antennal socket impunctate, shining.

Collar of pronotum well developed ; mesoscutum very strongly, densely punctate ; scutellum slightly more coarsely punctate than in mesoscutum ; propodeum rather short like female; propodeal enclosure finely reticulate, rather dull ; area lateral to propodeal enclosure densely, rather strongly punctate ; pre- and meso-episternum strongly punctate and rather coarsely sculptured; precoxal carina strong.

Legs robust, rather long ; femora and tibiae of hind legs more or less swollen ; tarsi of mid and hind legs long, with large claw-segments and claws.

Metasoma subcylindrical, well convex dorsally ; three basal terga largely exposed and apical terga retractile ; 1 st tergum well developed, distinctly convex laterobasally ; 2nd tergum transversely well convex, distinctly constricted at base ;

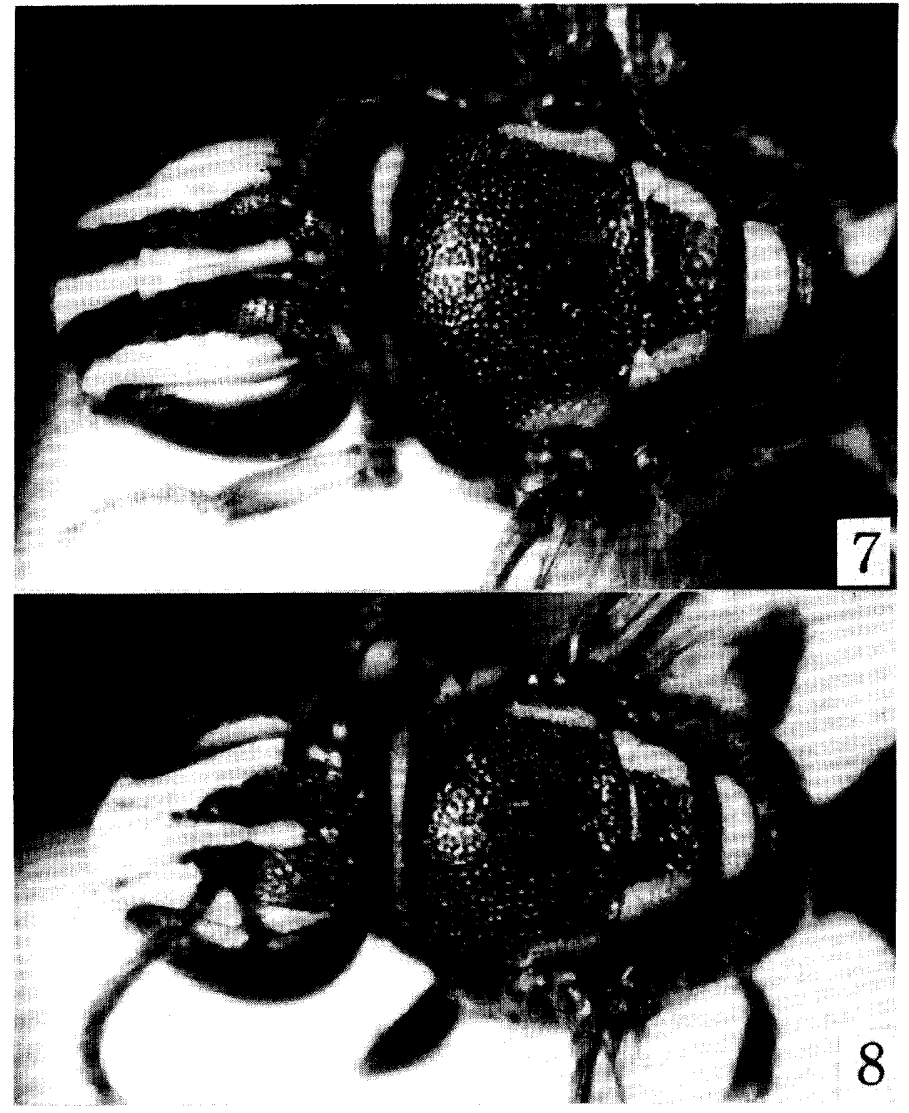

Figs. 7 and 8 Palaeorhiza (Cnemidorhiza) helena, new species. 7 : Dorsal view of the head and thorax of female. 8 : Ditto, male. 
metasoma distinctly, densely punctate; impunctate apical margin of 2nd tergum distinctly indicated medially, that of 3 rd broader than that of 2 nd ; sterna without special modification.

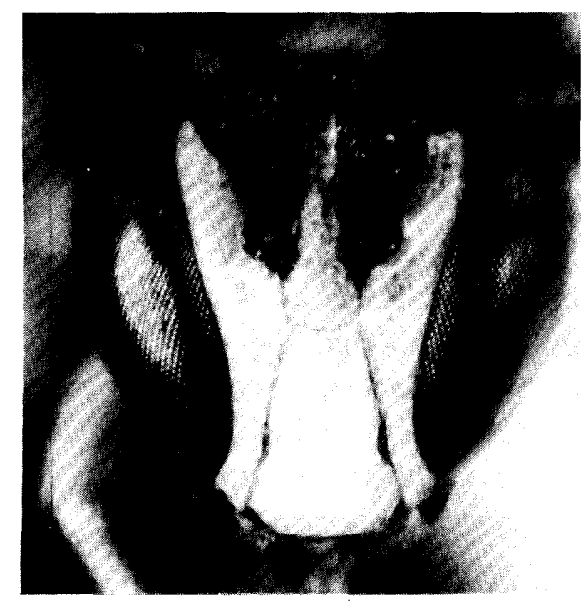

Fig. 9 Palaeorhiza (Cnemidorhiza) helena, new species. Frontal view of the male head.

Color : Head and thorax blue-green with following marks or portions yellow : clypeus, stripe on supraclypeal area, paraocular area, stripe on genal area along eye margin, labrum, mandible except reddened apex, band on pronotum, stripe on mesoscutum along lateral margin, axilla, lateral mark on scutellum, broad band on metanotum, tubercle, and a large mark on pre-episternum behind tubercle. Antennae entirely without yellow marking. Wings subhyaline; veins and stigma brown; tegulae ferruginous subhyaline, with a yellow spot. Legs reddish brown, with yellow markings or portions as follows: tibiae and tarsi of fore legs, apex of fore femora, tibiae and tarsi of mid legs except brownish patch on tibia and brownish claw-segment, and basal half of hind tibia ; tibiae and tarsi of all legs nearly all yellow in one specimen. Two basal terga blue-green with slight to strong purple tint ; 3rd tergum beautiful purple or violet, with blue or blue-green tint on lateral portion ; sterna piceous with slight purple tint.

Pubescence : Not conspicuous; white on head and thorax with brownish hairs on frons, vertex, mesoscutum and scutellum ; two basal terga with white hair fringes of short, not specially dense hairs on apical margins laterally; hairs on apical segments fuscous.

Type material : Holotype female, 1 paratype female and 2 paratype males, Manki L. A., Bulolo Valley, Morobe Province, on Evodia flowers, 25. iii. 1981 (H. Roberts).

Distribution : Papua New Guinea.

The name of this new species is derived from the Greek mythological name Helene. 


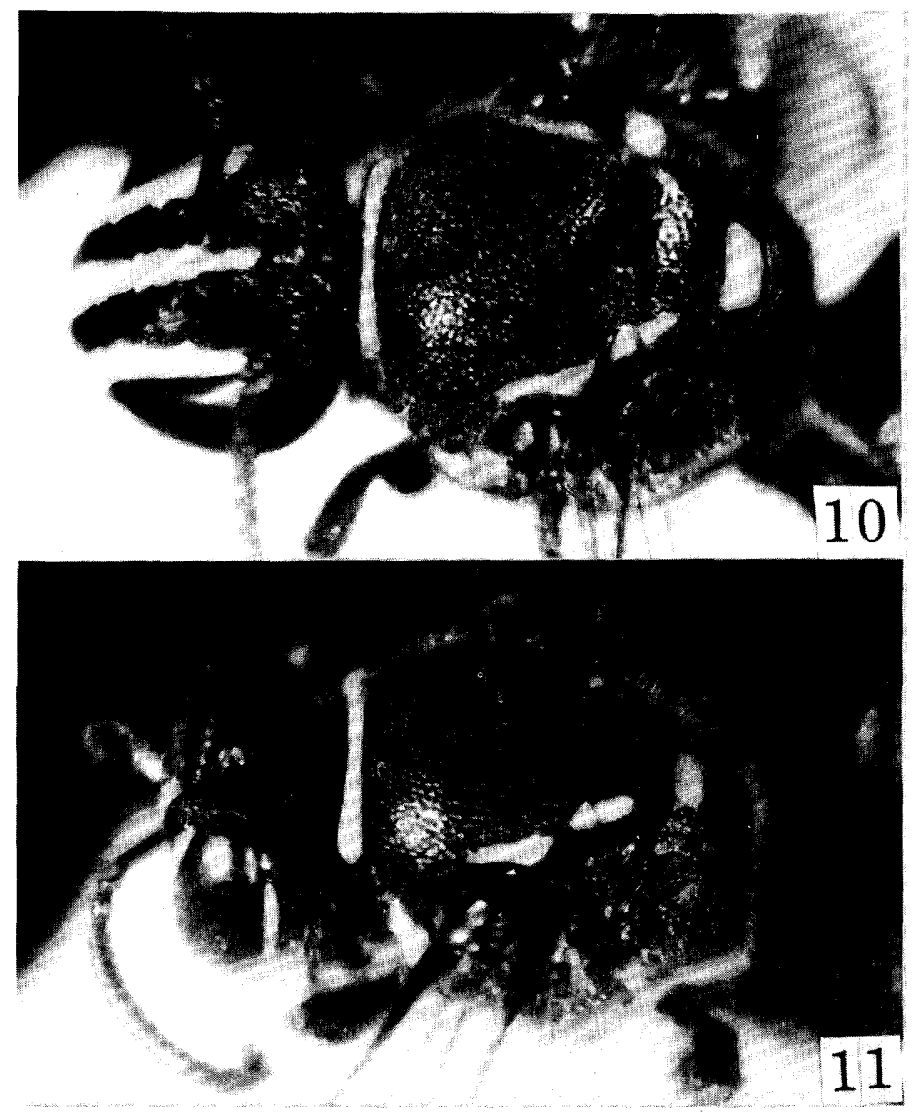

Figs. 10 and 11 Palaeorhiza (Cnemidorhiza) kraussi Hirashima. 7 : Dorsal view of the head and thorax of female. 8 : Ditto, male.

(10) Palaeorhiza (Cnemidorhiza) kraussi Hirashima

Female (new to science) : Length about $8.5 \mathrm{~mm}$.

Relative head measurements : width, 34.5 ; length, 31.0 ; upper interocular distance, 17.0 ; width of face, 21.5 ; lower interocular distance, 17.5 ; eye length, 25.0 ; clypeal length, 12.0 .

Very close to the female of $P$. pembertoni Hirashima, but differs from it as follows : Smaller; punctures on head and thorax much weaker (although close as in pembertoni) ; punctures on metasomal terga, especially those on 2nd and 3rd terga, weaker ; upper portion of supraclypeal area more highly elevated ; precoxal carina on mesepisternum distinctly weaker and lucking a median longitudinal carina (very strong and reverse T-like in pembertoni) ; yellow stripe on mesoscutum along tegula longer and yellow mark on metanotum larger.

Specimens examined : One female and 3 males, Manki L. A., Bulolo Valley, on Rubus flowers, 16. vi. 1981 (H. Roberts). 


\section{(11) Palaeorhiza spectabilis, new species}

This is a remarkable species which is easily recognizable by the combination of the following characters : Body distinctly metallic blue-green with some yellow markings on head and thorax, thorax very strongly punctate except propodeum and metepisternum, propodeal enclosure strongly wrinkled except apical portion, female hind tibia longitudinally ridged dorsally and coarsely sculptured (punctate) basally (as in Cnemidorhiza) and female hind femur provided with a dense tuft of short black hairs apically (also as in Cnemidorhiza).

This species may be included either Trachyrhiza Hirashima or Cnemidorhiza Hirashima. However, the subgeneric position of this new species is suspended until the female of Trachyrhiza is taken and its characters are examined.

Female : Robust, length about $8.5 \mathrm{~mm}$.

Relative head measurements : width, 39.0 ; length, 34.5 ; upper interocular distance, 19.2 ; width of face, 24.0 ; lower interocular distance, 19.5 ; eye length, 27.0 ; clypeal length, 14.8 .

Mandible weakly bidentate ; malar space slightly less than one-half of basal width

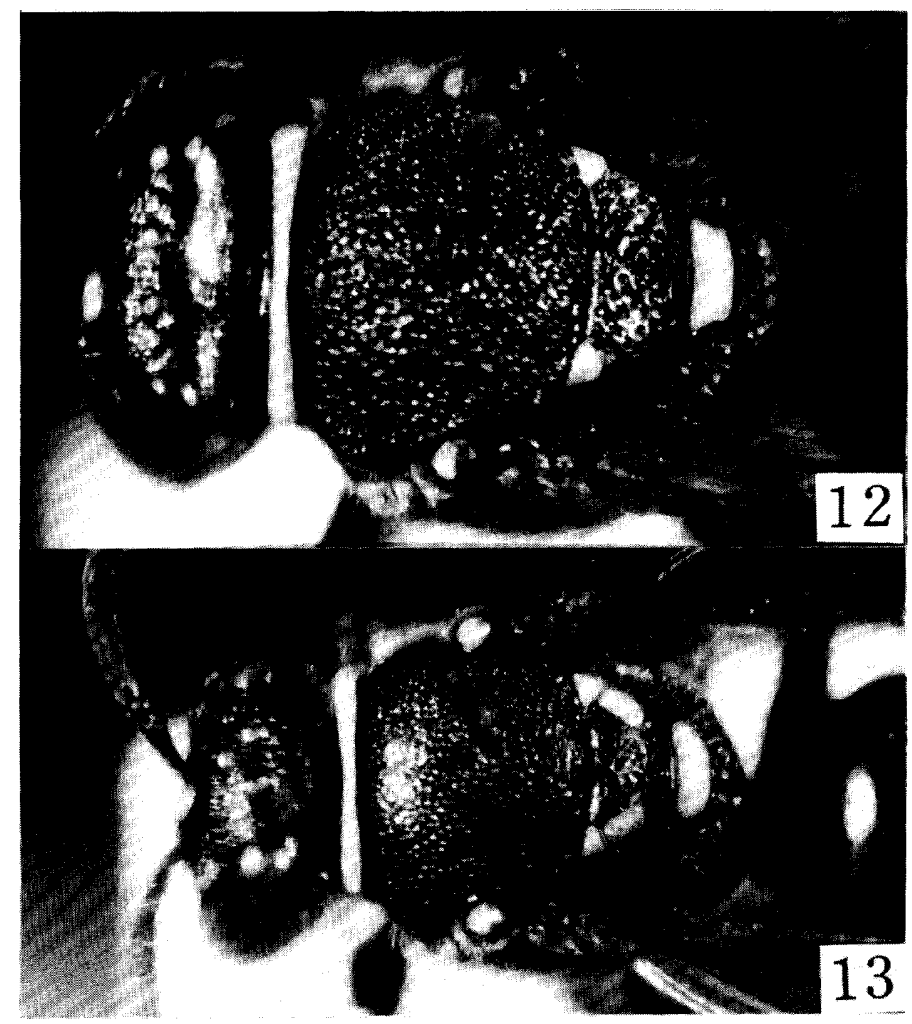

Figs. 12 and 13 Palaeorhiza spectabilis, new species. 12 : Dorsal view of the head anc thorax of female. 13 : Ditto, male. 
of mandible ; clypeo-ocular distance longer than malar space ; clypeus strongly convex ; supraclypeal area also strongly convex, converging and lowered above ; frons above antennal base flat; vertex behind ocelli strongly slanting behind ; posterior ocelli rather widely separated each other ; ocellocular distance a little longer than interocellar distance. Clypeus and paraocular area below antennal base very shining, with sparse, very weak punctures; vertex well punctate, punctures becoming weaker toward antennal base.

Collar of pronotum transversely well ridged with sharp anterior margin ; mesoscutum, scutellum, pre-episternum and mesepisternum very strongly, densely punctate, interspaces between punctures almost linear, microscopically reticulate, weakly shining ; scutellum nearly flat ; metanotum weakly and sparsely punctate on colored portion, densely punctate on lateral portion ; propodeal enclosure strongly wrinkled except apical portion; propodeum and metepisternum not coarsely sculptured ; precoxal carina on mesepisternum strong.

Legs more or less robust ; fore tarsi more or less long ; 2nd segment of fore tarsus a little longer than broad, a little larger than next segment; inner spur of hind tibia broadened subbasally, well curved ; hind tibia longitudinally well ridged dorsally, rather broad and coarsely sculptured (punctate) basally; apex of hind femur with a dense tuft of short black hairs.

Metasoma well convex, with three basal terga broadly exposed and three apical terga retractile ; 1 st tergum more or less short, well convex latero-basally ; apical margin of 2nd tergum slightly emarginate on sublateral portions ; latero-apical corner of 2nd tergum acute. Three basal terga more or less well punctate ; 2nd tergum with apical impunctate margin well indicated on median portion ; 3rd tergum with apical impunctate margin rather broad, microscopically lineolate, dull.

Color : Head and thorax blue-green with following markings yellow: three stripes on face (the median one disappeared on lower portion of supraclypeal area in one specimen), long stripe on genal area along eye margin, entire band on pronotum, triangular mark on axilla, small mark on scutellum next to axilla, broad band on metanotum, apical mark on tubercle, and a spot on tegula ; in one specimen, a small spot on mesepisternum just below tegula; clypeus and lower face shining. Wings distinctly brownish; stigma and veins fuscous. Legs black or piceous with slight purple tint ; basal marks or spots on fore and mid tibiae yellow. Metasomal terga dark blue-green with purple tint, shining; sterna black or piceous with slight metallic reflection, shining.

Pubescence : Not conspicuous; hairs on vertex, mesoscutum, scutellum and sides of metanotum fuscous ; hairs on metepisternum and sides of propodeum white, very short, not conspicuous ; metasomal terga without fringe of hairs ; hairs on metasoma mostly fuscous.

Male : Smaller than female.

Relative head measurements ; width, 32.5 ; length, 30.5 ; upper interocular distance, 16.0 ; width of face, 19.0 ; lower interocular distance, 12.5 ; eye length, 24.8 ; clypeal length, 12.5 . 
Agrees with the description of female except as follows : Inner eye margins distinctly converging below ; malar space slightly shorter than base of mandible ; clypeo-ocular space about as long as malar space ; clypeus not highly convex ; upper portion of supraclypeal area abruptly reduced its height ; scape not long ; flagellum long, two basal segments broader than long respectively, 3rd segment longer than broad, about as long as 1st and 2nd combined ; femur and tibia of hind leg unmodified ; metasoma elongate, distinctly punctate; median yellow stripe of face broadened on apical portion of clypeus ; labrum with a yellow spot; fore tibia broadly yellow anteriorly ; a basal spot on hind tibia yellow.

Type material: Holotype female and 3 paratype females, Divide L. A., Bulolo Valley, on Harpullia flowers, 7. ix. 1982 (H. Roberts) ; 2 paratype males, the same locality, 8. ix. 1982, on Harpullia flowers (H. Roberts).

Distribution : Papua New Guinea. 